\title{
Red Sea Folk Beliefs: A Maritime Spirit Landscape
}

Dionisius A. Agius, University of Exeter

When a wave covers them like the canopy (of clouds), they call to God, offering Him sincere devotion.... ${ }^{1}$

\section{ABSTRACT}

The Red Sea brings together the coastal communities and seafarers of Africa and Arabia through a variety of folk beliefs and superstitions, which manifest something of a common tradition through time and space. This article explores a conceptual framework that might be called a "spiritscape," an amalgam of ideas and practices that embrace multiple layers of human and nonhuman relationships and interactions within the landscape and seascape of the Red Sea world.

\section{Introduction}

Folk beliefs and practices reflect what people think and do, the lives they live and the meaning they give to their experiences. ${ }^{2}$ However, defining "folk belief" is doubly problematic because there is no consensus as to the definitions of either "folk" or "belief." Folklorists have offered many 
definitions of belief, though "the quest for a broadly based pragmatic theory" mentioned by Richard M. Dorson in $1963^{3}$ continues even after fifty years. If "belief" is problematic to define, "folk" is even more so. Nonetheless, the subjects of maritime and land folk beliefs in the Red Sea's southern region have been covered in various works by Hornell, ${ }^{4}$ Myers, ${ }^{5}$ LeBaron Bowen, ${ }^{6}$ Serjeant, ${ }^{7}$ Johnstone, ${ }^{8}$ Naumkin, ${ }^{9}$ and Smith, ${ }^{10}$ to mention a few. These studies show the circulation of and material culture associated with such beliefs, but a wider approach to the subject is here proposed.

This article centers round the belief in the "spirit" and the supernatural ${ }^{11}$ in a maritime landscape. Although there exists a substantial anthropological literature on concepts related to religion, superstition and magic, including their performative and symbolic dimensions, my aim here is more modest. ${ }^{12}$ The present study is primarily empirical, based on ethnographic fieldwork. It builds on Westerdahl's conceptualization of a "maritime cultural landscape" to explore the role that the spiritual and the supernatural world play in the multi-faceted network of human activity by and at sea. ${ }^{13}$ Although Westerdahl's original concept posited a divide between land and sea, D. B. Tuddenham has challenged this. ${ }^{14}$ Tuddenham argues the cultural landscape to be physical and cognitive, thus combining the coastal environment, the coastal society, and the cultural space (social practices), and he coined the term "maritimity" to explain this relationship between the land and sea. ${ }^{15}$ What exactly is "maritimity?" It is a complex question because it is impossible to arrive at "a precise definition." Land and Sea remain dichotomic: Nature and Culture. ${ }^{16}$ Jorge Vaz Freire, in his recent archaeological study of the coast of Cascais, near Lisbon, provides "a model of scientific interpretation" for the maritime cultural landscapes by focusing on issues of "continuity, social dynamics and mental and natural perceptions of the region."17 These issues (taking out the archaeological approach) can be applied to the present study on Red Sea folk beliefs. One problem with the term "culture" is that it is also difficult to define; many such definitions are vague but one that sums it up aptly is D. Matsumoto's: "the set of attitudes, values, beliefs, and behaviors shared by a group of people, but different for each individual, communicated from one generation to the next." ${ }^{\prime 18}$ Matsumoto's definition fits the proposed maritime spirit landscape, a framework that encompasses the material and nonmaterial/ human and nonhuman practices and their engagement with the environment and the sea. 
The sea folk beliefs in this study are, to borrow Stuart A. Vyse's terminology, "socially shared superstitions." ${ }^{19}$ In the maritime spirit landscape of the southern Red Sea, these superstitions are manifested in a number of concrete practices, which include invoking prayers, wearing talismanic objects, decorating ships, visiting holy men's tombs, and belief in spirits. In addition to exploring the relationships between local communities and the physical environment that shape their lives, this article asks why the Red Sea is rich in folk beliefs, superstition, and the supernatural. And why do some sea folk beliefs persist and others disappear? The two areas of beliefs and practices focused on in this article are that of magic on the coast and at sea and of the power of sea jinns.

\section{The Fieldwork}

After surveying written evidence from medieval Arabic historical works and travel material from the early modern and modern periods, two ethnographic field trips were undertaken in the southern region of the Red Sea with the purpose of documenting folk beliefs and recording material-cultural magical practices of contemporary seafarers and coastal residents. Visits were made to Tadjoura and Obock in Djibouti (2009) and Greater Farasan (Farasan Al-Kebir), and Segid and Qummah in the Farasan Archipelago of Saudi Arabia (2010). ${ }^{20}$ A number of informants were contacted in the course of the field trips and semi-structured interviews were conducted with ten men of different ages, either retired or still working: three sea captains aged 81, 77 and 76; a sailor, 79; two fishermen/pearl divers in their 70s; a sea captain, 55; a folklorist in his 50s; a fisherman/ pearl diver, 46; and a guide about 44 years old. Although the main fieldwork was conducted in Djibouti and Farasan Island, a few examples cited in the article are drawn from other places I visited in the Red Sea region, namely Sudan (2004), Yemen (2009), and Eritrea (2013).

The Republic of Djibouti ( $\left.11^{\circ} 36^{\prime} 0^{\prime \prime} \mathrm{N}, 43^{\circ} 10^{\prime} 0^{\prime \prime} \mathrm{E}\right)$ lies at the far corner of the Horn of Africa: Assab in Eritrea lies to the north, Somaliland and Puntland to the south and, across the sea on the Arabian coast, Aden and Mukalla to the northeast (see Figure 1). Djibouti became independent from France in 1977. It covers 23,206 square kilometers with 370 kilometers of coastline and a population of 903,000 (2016 est.) and its capital has been 


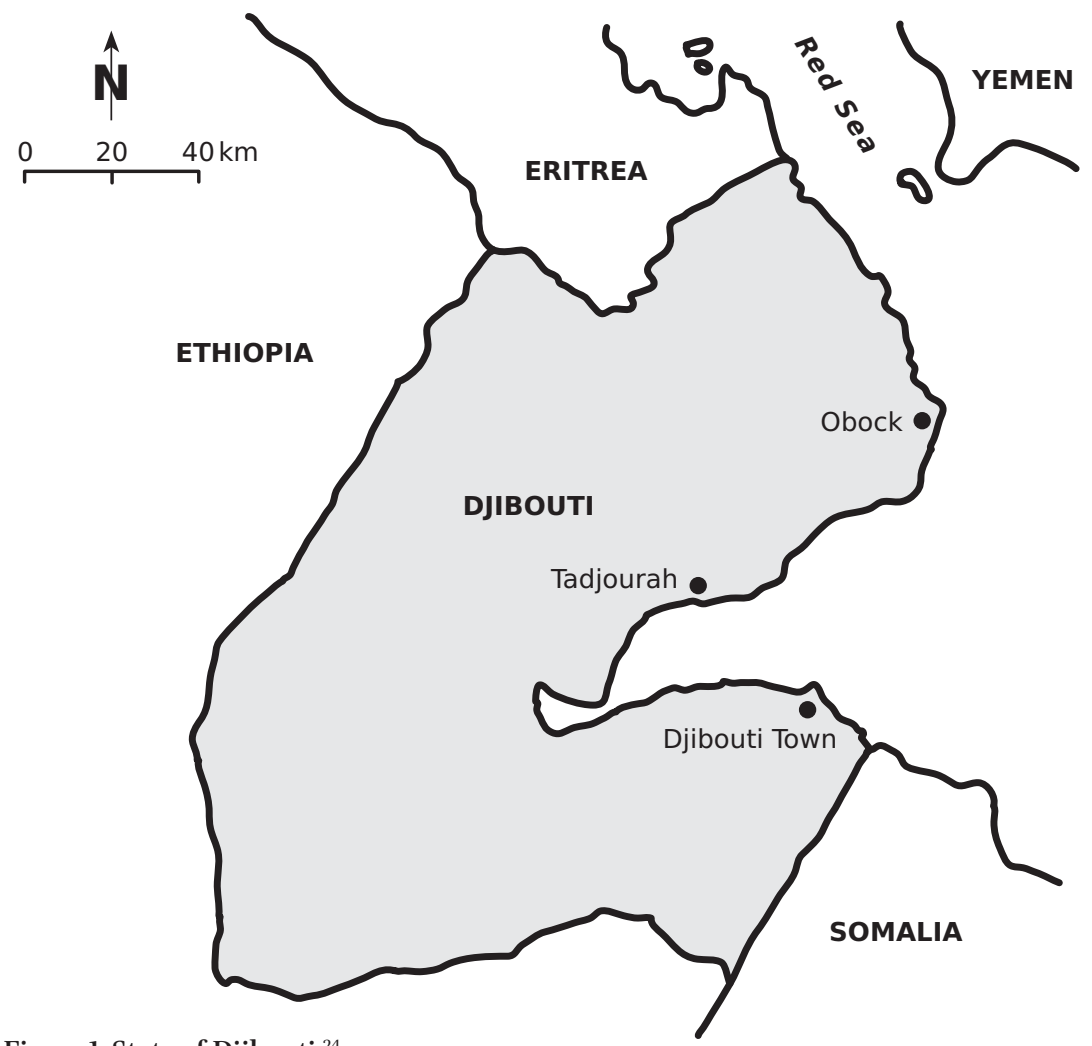

Figure 1. State of Djibouti. ${ }^{24}$

Djibouti city since $1896 .{ }^{21}$ About 173 kilometers northwest of the capital is the fishing town of Tadjoura, once an important medieval harbor. ${ }^{22}$ It is today the residence of the sultan. The Afars of Djibouti are the original settlers; they are cattle herders and farmers. During the colonial and independence periods, Somali and Ethiopian ethnic groups settled in Djibouti; today they constitute a large part of the population..$^{23} \mathrm{~A}$ third minor ethnic group, the Yemenis, are fishermen and/or occupied with maritime trade. It is the latter that I had contact with during my fieldwork. There is still an active trade among Tadjoura, Djibouti, and Obock, as well as between Djibouti and the southern Yemeni coast.

The Farasan Islands $\left(16^{\circ} 40^{\prime} \mathrm{N}\right.$ and $\left.42^{\circ} 00^{\prime} \mathrm{E}\right)$ comprise an archipelago of 128 islands belonging to Saudi Arabia, with an area of 3,310 square kilometers in the southern Red Sea. The archipelago lies north of Yemen, 


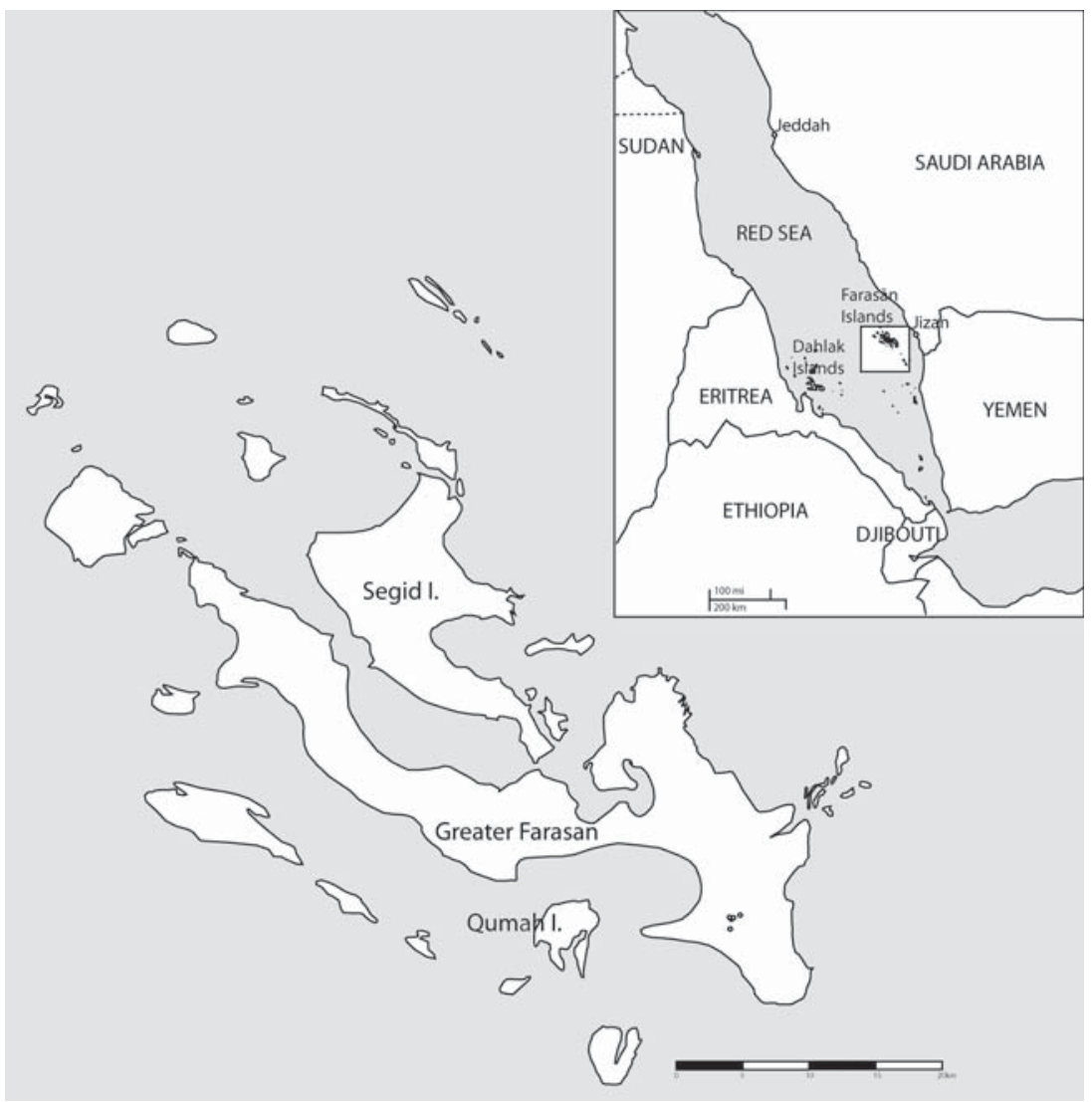

Figure 2. Farasan Islands opposite Jizan town on the Saudi coast. (Drawing by Chiara Zazzaro and John P. Cooper.)

south of Jeddah, about 40 kilometers offshore west of the port town of Jizan and some 280 kilometers east of the Dahlak Islands off the Eritrean coast. The islands are connected with the Saudi coast by ferry (see Figure 2). The Farasan islanders historically lived off fishing and pearling. A total population of around 5,000 lives on the main island of Greater Farasan, Segid, ${ }^{25}$ and a population of some 455 fishermen and their families live on Qumah Island; until some years ago, several were engaged in pearl diving and shell collecting. ${ }^{26}$ There are still a large number of fishermen on Greater Farasan and Segid, although much of the population now work for the governorate of the island, for the Jazan regional government, and in the private sector. 


\section{Background to the Study}

Trade and pilgrimage have been the main drivers of population movements in the Red Sea region. It should be said that trade and pilgrimage were often combined. With the introduction of the Islamic pilgrimage, people from North Africa and, in particular, India came to Jeddah, and mixed with the already established cosmopolitan communities and the Arabian Bedouins. A substantial number of pilgrims and traders also settled in Aden, Mocha, Massawa, and Suakin. ${ }^{27}$ Another significant population movement involved the thousands of slaves who were sold from Africa to Arabia and who, after their emancipation in the early twentieth century, never returned home but instead settled on the Red Sea Arabian coast or inland. And in the reverse direction, Yemeni and Arabian tribal migrants left Arabia to make a living on the African coast as fishermen and traders or as cattle herders inland. ${ }^{28}$

The Red Sea is one of the most dangerous seas in the world. Seafarers fear it and there are many anecdotes concerning survival in its perilous waters. In addition to unpredictable gales and numerous coral reefs that could wreck their boats, passengers and mariners alike also feared piratical raids that typically resulted in looted possessions, damaged vessels (which were sometimes set on fire), and even the loss of voyagers' lives. The fear of physical danger from the natural environment went together with a strong belief in the powers of destructive spirits who existed by and on the sea. These beliefs persist today to varying degrees in parts of the Red Sea, together with the rituals and folk practices that accompany them.

\section{Belief in Magic}

Superstitious folk beliefs about the power of the sea and its ability to attract evil forces have been documented in the region going back centuries. For example, the Yemeni historian Ibn al-Mujāwir (d. 690/1291) reports a ritual performed by mariners on board ships calling on the island of Socotra, noted for its unpredictable winds and storms. As the mariners approached the island at a place called Al-Suq, east Hadibo, they put "some food stuffs consisting of a little coconut, salt and ashes" in a clay pot fitted with a sail and rudder, which they then threw into the sea. ${ }^{29}$ The Egyptian historian 
al-Nuwayrī l-Iskandarānī (fl. eighth/fourteenth century) documented a similar ritual in which a jar stuffed with salt, ash, and cooked rice, and topped with a candle, was set afloat as the mariners stated: "This is an offering to the sea." ${ }^{30}$ The practice of throwing food to the sea continued well into the modern period: James Wellsted (d. 1842) of the Indian Navy, surveyor of the Arabian Peninsula coast, wrote that the sailors passing through the Bab el-Mandeb "mutter[ed] ... in their progress many prayers, and casting loaves of bread into the sea." ${ }^{31}$ Here Islamic invocations are said but the shamanistic practice of the offering of loaves to the sea remains. Oliver Myers, an ethnographer in the mid-twentieth century, reports of Adeni fishermen offering gifts to sea creatures. ${ }^{32}$ Interacting with nature and seeking its intervention to cast away evil spirits gives people a sense of "security" on the coast and inland. Bertram Thomas, a British civil servant, in the 1920s saw the people on the Qara mountains of Dhufar, Oman, throwing pieces of food and tobacco: "we are your sons, your daughters; do not harm us." The cry for help was to protect them from "malign spirits" but also "evil men." ${ }^{33} \mathrm{He}$ commented that "the knowledge" of perils and dangers the people of Southern Arabia face have "implanted in them ... a combination of trust in the supernatural that is childlike in its simplicity"34_a somewhat patronizing comment that does not recognize the universal nature of such beliefs.

Superstitious beliefs continue to have deep resonance through sihr (magic), which is, among other things, related to, as T. Fahd has put it, that "which entrances the eye and acts on the psyche of the individual, making him believe that what he sees is real when it is not so." ${ }^{35}$ Practices associated with sihr $r$ are often contemporary manifestations of shamanistic practices that predate Islam. However, the relationship between cause and effect in these practices is not always clear-cut for the practitioner. The goals of specific practices are not always apparent and, as a result, the effect is often difficult to interpret. Sonja Hukantaival ascertained that "although the effect is believed to be a result of the action (not necessarily caused by a helping 'supernatural' being), the relationship between cause and effect does not follow the causality of action." ${ }^{36}$ Nevertheless, the majority of the seafaring population of the southern Red Sea is well-aware of the necessity for warding off evil, hence the "need" for material objects, prayers, and — on land—visiting saints' tombs. 


\section{Material Objects}

Communicating with the natural and supernatural world is manifested by wearing or exhibiting material objects. The more Red Sea people are exposed to the dangers of the sea, or fear they are haunted by troublesome spirits on land and at sea, the more they feel the need for material objects such as the evil eye, an object that protects against malevolent acts and spiteful spirits. ${ }^{37}$ The rituals relating to the evil eye (al-cayn) are particularly important for the southern Red Sea communities, as they are in the Horn of Africa and along the East African coast. Intentionally casting an evil glance is generally believed to be capable of cursing others and causing destruction. There are many objects believed to offer protection against the evil eye, such as the bayraq or saint's emblem worn at one time by Yemeni sailors. ${ }^{38}$ Sea shells and fish bones are still worn as amulets to protect the coastal people and seafarers. ${ }^{39}$ They perform the magic that, as Bronislaw Malinowski points out, give that "added confidence" needed by the wearers. ${ }^{40}$ Such amulets are seen not only to protect the bearers against negative energy but also to help ensure shell collectors, for example, of a good catch. These objects are still used and people still believe in their magical and spiritual powers, just as the wearing of amulets containing Qur'ānic verses or magic oral formulas recited in Egypt and Sudan serve as protection against the evil eye.

Fear of the evil eye affects the decoration of indigenous boats sailing in the Red Sea. Stylized depictions of the eye (oculus) on boats were common because they were seen as also offering a talismanic power against mischievous spirits. ${ }^{41}$ This practice has been well-documented. James Hornell (d. 1949), a maritime ethnographer and zoologist, has shown that it has old ancestry and that it has been a common practice throughout the Indian Ocean and Mediterranean Sea. ${ }^{42}$ In the Red Sea and East Africa, oculi were often painted on both sides of the bow, the stern, ${ }^{43}$ or the stem head (Figure 3). ${ }^{44}$ Such carving and painting of the eye is found on Chinese junks, as Alan Moore noted in the 1930s, and like the Arabian, Persian, and Indian dhows, protects the vessel and the crew against evil acts and spirits. ${ }^{45}$ Though it used to be customary to paint a stylized blue eye with a white dot on either side, this practice has faded in the Red Sea. Nonetheless, on one occasion I saw this modified oculus on a fiberglass boat at Obock, Djibouti (Figure 4). 

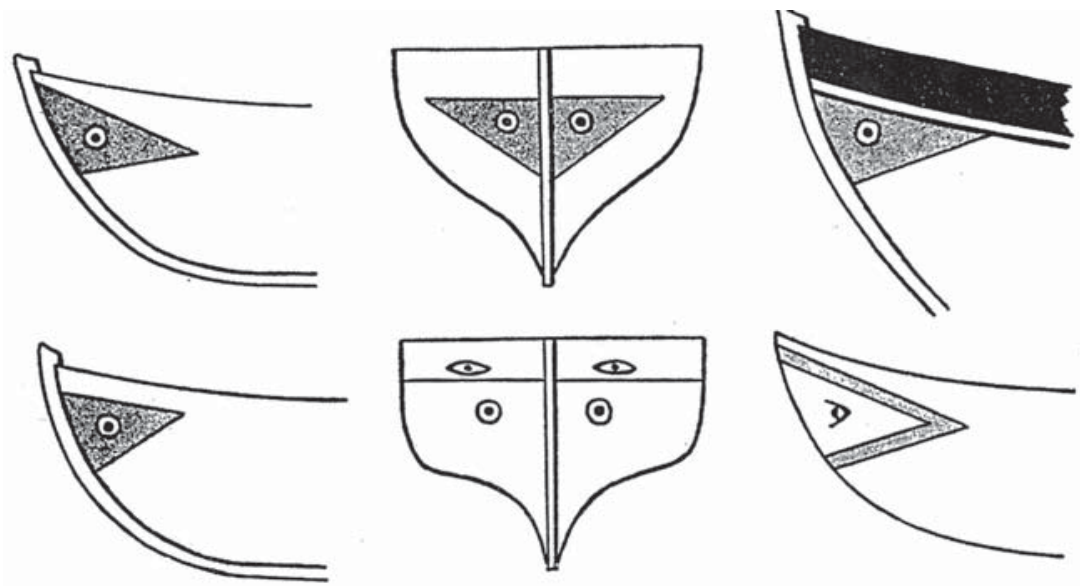

Figure 3. Occuli on East African Zanzibari dhows (after LeBaron Bowen). ${ }^{46}$

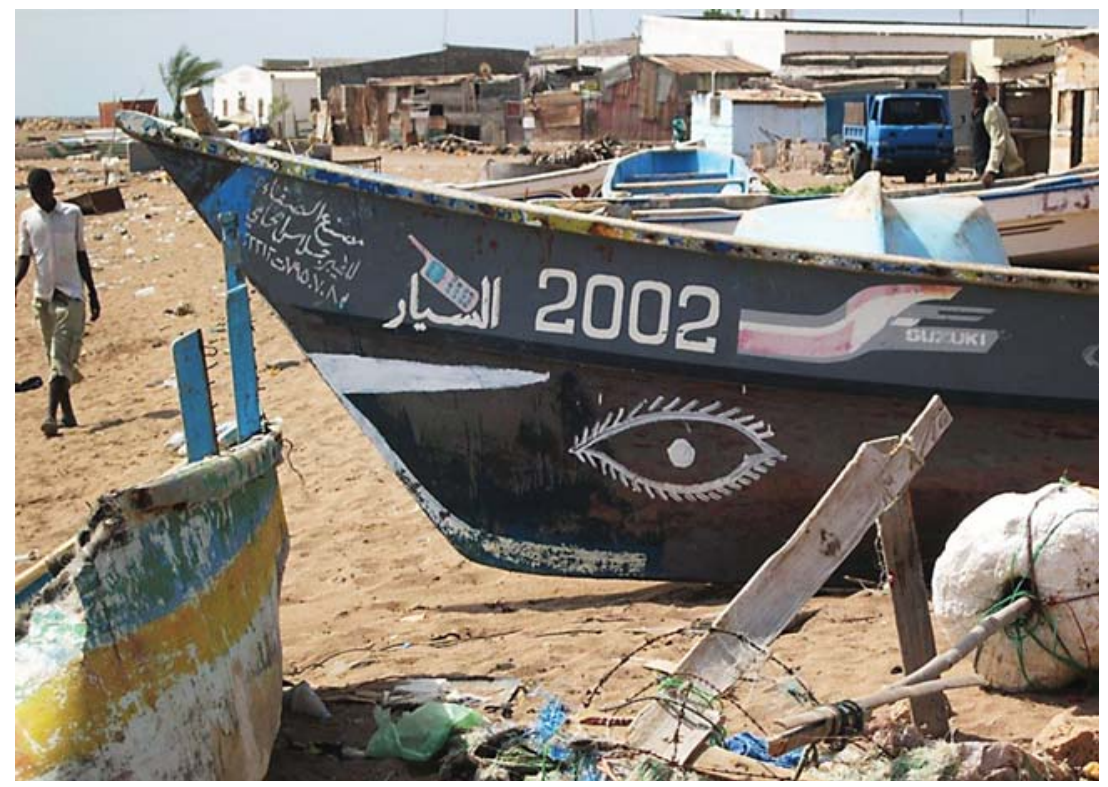

Figure 4. An Obock fiberglass boat with an oculus painted unconventionally below the bow, 2009. (Photo by D. A. Agius.) 
Depictions of eyes are not the only decorative element believed to offer talismanic protection from evil at sea. Other potent decorative forms include flower patterns, circles, triangles, zigzags, and stars. They are either engraved or painted onto the ship. ${ }^{47}$ There is no particular pattern followed ritualistically by carpenters and owners; each motif is drawn with an individual preference. Colors also have specific ritualistic purposes at sea, perhaps an inheritance from pre-Islamic traditions. Dhows in Sudan, Djibouti, and the Yemen are painted in different bright colors: red or red ochre, green, yellow, black, and white, with blue and turquoise blue being the dominant colors; the latter two are considered especially talismanic (Figure 5). ${ }^{48}$

In addition, artefacts that were once used to adorn the ship are believed to have had the power to keep evil forces out. Tassels on ships represented blessings and held magical powers to avert evil. Umbrellashaped pendants containing a long tassel were hung from the "jib-boom end" on some pilgrim ships. Tassels were hung from the stem head of pilgrim ships as Morton Nance's drawing shows (Figure 6). ${ }^{49}$ Ostrich eggs are another artefact that were brought on board to help protect the ship while at sea. This practice has deep roots. In 1700, William Daniel, an adventurer who undertook an expedition from London to Surat (NW Indian coast), embarked on a ship "ornamented with ostrich eggs and feathers. ${ }^{50}$ Ostrich eggs also were believed to have magical powers on shore. Archaeologists have concluded that they were hung from the ceiling of buildings such as the burial places in Quseir al-Qadim on the Egyptian coast. ${ }^{51}$ Through such material objects the people of the sea maintain a physical and emotional connection with the supernatural world, which gives them confidence and reassurance in their daily lives.

Further, it is my contention that texts written on the boat, either in the form of the boat's name or in the writing of poetic verses, should be seen as offering another layer of protection. The naming of boats is a common practice in the southern Red Sea region, one that I did not find in the Arabian Gulf and Oman. Names for boats include bashā'ir (good omens), ar-raḥhāl (the wanderer), rajä' (hope), as-salām (peace), janāh aș-șaqr (the falcon's wing), and umm al-khayr (the mother of goodness). In the early twentieth century, N. F. J. Wilson of the Royal Indian Marine remarked: "The motive underlying the choice of every name in ordinary use is the desire to escape danger or to experience good luck." ${ }^{n 3}$ Although 


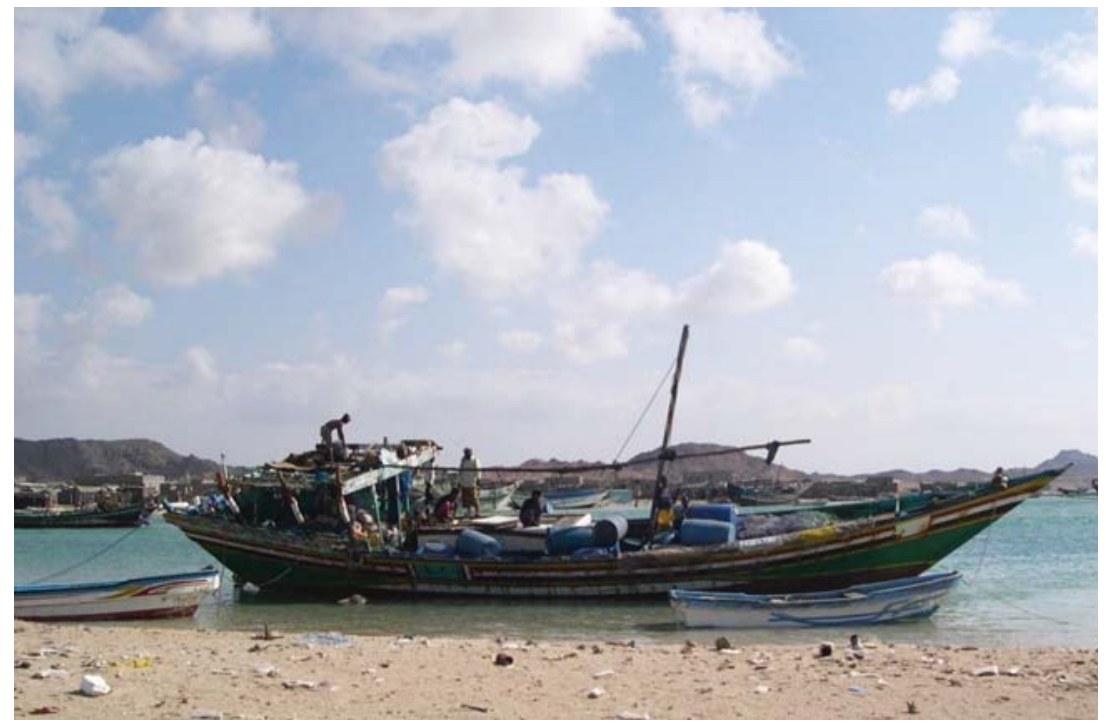

Figure 5. Bright colors and motifs on dhows at Khor al-Ghureirah, Yemen, 2009. (Photo by D. A. Agius.)

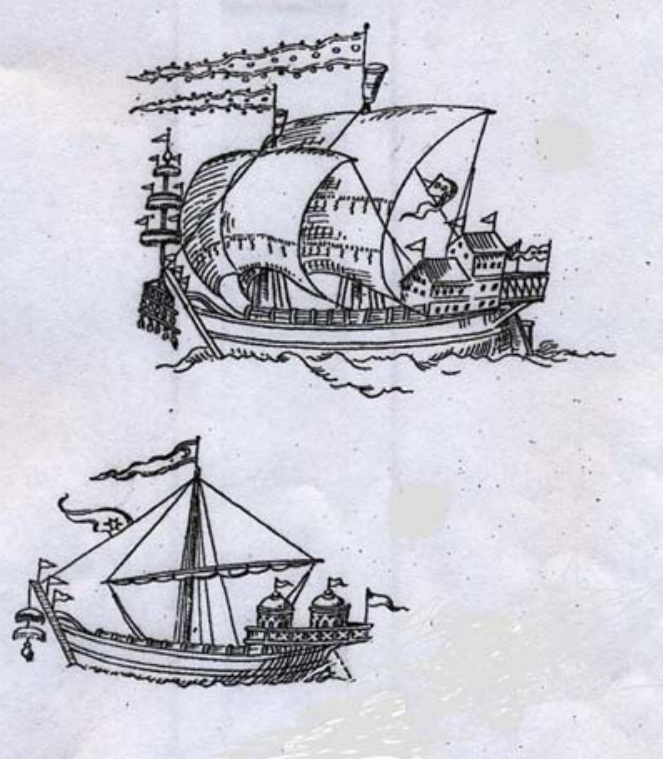

Figure 6. Bow-

ornaments: tassels and ostrich eggs; drawing of eighteenth-century pilgrim ships (after Morton Nance). ${ }^{52}$ 
the specific name is important, the particulars of a poetic verse inscribed on the boat need not be. The talismanic power does not come from the content of the verse itself. Rather it is derived from the belief of the fishermen on board that the words themselves have talismanic power. For example, one such talismanic poetic verse that I saw in Suakin, Sudan, read: "If the distance between us is miles our friendship outweighs the mountains" (law al-masāfa baynanā bil-amyāl baynanā al-qarāba tuzin al-jibāl) (Figure 7).

There are a number of other superstitious rituals associated with building and launching a new ship. Siraj Muhammed Siraj of Massawa, Eritrea, 41 years old, informed me that "they do not cut the wood of a mangrove tree (Avicennia rasofora) in full moon because the wood gets powdery (ifatfat). ${ }^{n 4}$ These beliefs often incorporate the ritual sacrifice of an animal. For example, as explained Muhammad Hasan Mahmud, 50 years old, before a new ship is launched in Suakin, where dhow building is still active, the community slaughters a goat. Then "the blood is sprinkled on the planks as a blessing and a sign of prosperity and safety," and the goat's skin is fitted on the stem head as a sign of protection against the evil forces (Figure 8). ${ }^{55}$ Such practices, according to Wilfred H. Schoff's theory, may be interpreted as "atonement" or propitiation that could antedate animal sacrifice, ${ }^{56}$ a pre-Islamic form of appeasement of elemental forces that was later incorporated into religious rituals and that continues to be practiced as such. Another form of atonement was noted by Cyril Crossland (d. 1943), a British civil servant, in Suakin where people offered a sacrificial sheep in honor of the holy man. ${ }^{57}$ The offering is nonetheless made to God. Such practices are global and have a shamanistic base with later religious overtones.

Protective devices have ancestral links and are ubiquitous: amulets and talismans, their power enhanced by rituals, are commonly used and the belief in their powers is embedded in the Judeo, Egyptian, and Greco-Roman traditions in the West and others around the world. Magical thinking is not only confined to tribal populations as it was once believed ${ }^{58}$ but, as informants and travel literature have shown, it is prevalent among all levels of society. Why people attach themselves to magical belief is an important question. Is the greater prevalence of superstition and folk belief in the Red Sea due to the continuing reliance on the fishing industry and therefore to the peoples' ongoing connection to the sea? Is belief in magic an escape 


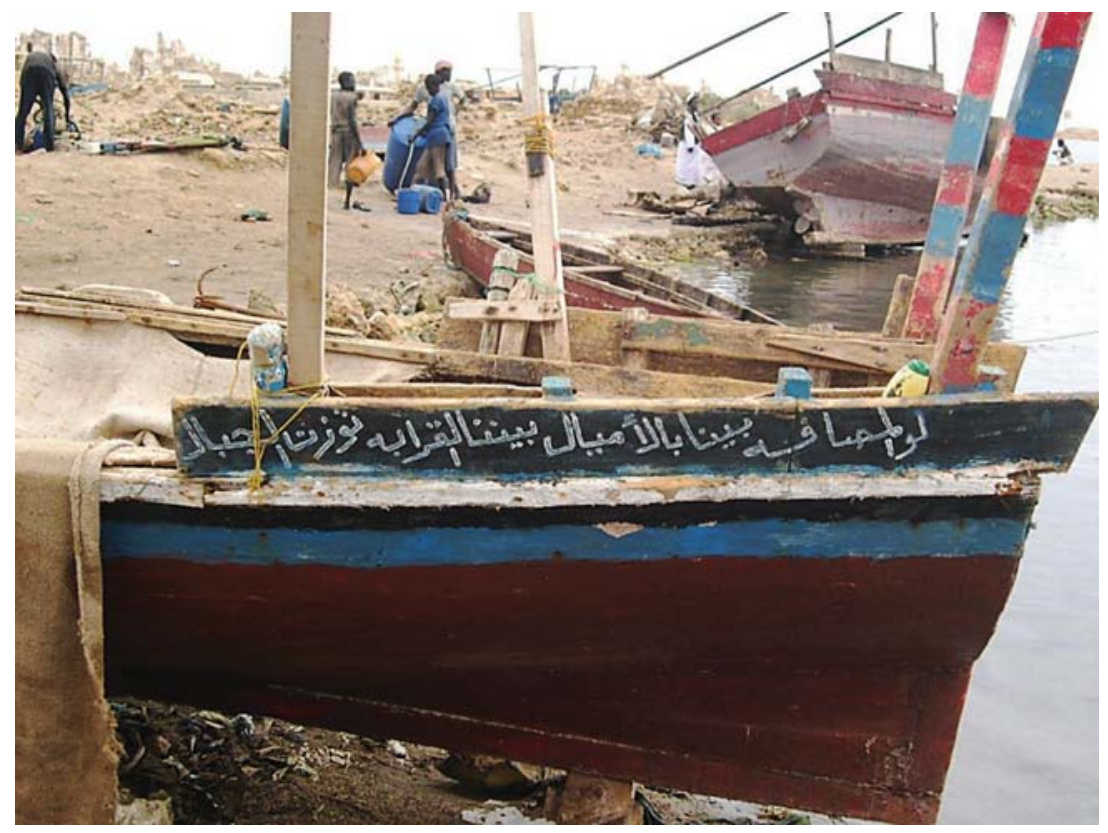

Figure 7. Textual drawing, Suakin, Sudan, 2004. (Photo by D. A. Agius.)

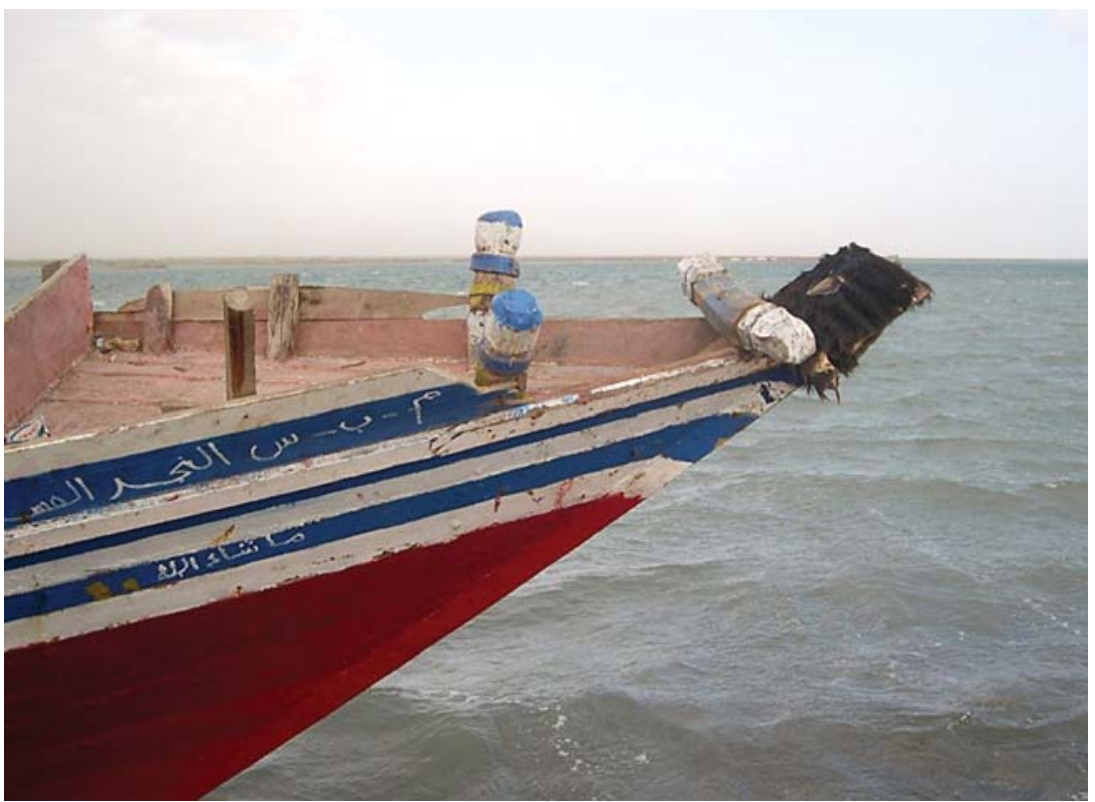

Figure 8. A Sudanese goat skin on a dhow's stem head—a mark of safety, 2004. (Photo by D. A. Agius.) 
from difficult periods of "uncertainty" and danger as Keinan has said?59 The Red Sea is a particularly dangerous arena for securing a livelihood, so it would be understandable that supernatural protection is invoked by prayers, talismanic objects, and tomb visitation.

\section{Prayers (ducā')}

Prayer or invocation is communion with God, trusting in his providence; it is a "prayer of request," ${ }^{10}$ different from the liturgical șalät. It is customary to invoke God's name bism illāh ("in the name of Allāh") during the day to ensure God's presence in all activity; more frequently in times of danger and on the perilous journeys seafarers take in the Red Sea. Crew members and passengers on board ship have traditionally used prayer to ask for God's assistance and protection. This continues today when voyagers recite the fátiḥa (the first Qur'ānic chapter) with raised hands in order to be reminded of Allāh's mercy. One Qur'ānic verse reminds the devout seafarer that he is left to the mercy of Allāh if the ship encounters a gale: "He it is who enableth you to traverse through land and sea; so that ye even board ships; - - they sail with them with a favourable wind, and they rejoice thereat; then comes a stormy wind and the waves come to them from all sides, and they think they are being overwhelmed; they cry unto God sincerely offering [their] duty unto Him, saying: 'If Thou dost deliver us from this, we shall truly show our gratitude."'61 There is a prayer often chanted by Djiboutians on board ship reciting: "[O Allāh] turn [these winds] away from us/O force against calamity/[O Allāh] turn [these winds] away from us" (hawwalaynā wa lā calaynā/ $y \bar{a}$ dāfic al-balā/ hawwalaynā wa lā calaynā $).{ }^{62}$ Prayers are often work songs that elevate the spirits of the workmen as they sing them when raising the yard, rowing, pushing and pulling the boat, or setting off and returning. The person who leads the prayer song begins it with a word or two followed by a short response sung in chorus by the sailors: "In thy way, O God/O Lord/ O God, in thy way this day/ O Lord/ we trust in God/ O Lord/ He who trusts God will help/ O Lord" ("alā bābak Allāh/yā mawlayya/yā Allāh calā bābak al-yōm/ yā mawlayya/aḥna tawakkalnā calā Allāh/yā mawlayya/wa min yuwakkil cānahu Allāh/ yā mawlayya). ${ }^{63}$

The practice of utilizing prayers of protection has a long history in the region. The Moroccan traveler Ibn Bațtūṭa (d. 779/1377) wrote that Abū 
l-Hıasan al-Shādhilī (d. 656/1258), a recognized holy man, encouraged travelers to recite the Litany of the Sea (hizb al-bahr) on board ship. ${ }^{64}$ This litany was still being recited at the time the explorer, Richard Burton (d. 1890) sailed from Suez to Jeddah. ${ }^{65}$ Reciting the litany is an act of piety and communal bonding with one's fellow travelers that gives a powerful sense of physical and emotional security. It is firmly believed that it offers protection, not only from treacherous winds and high waves but the dangers of evil spirits, and against "[the] plague, the evil eye" and other perils. ${ }^{66}$ Though there is much continuity in this practice, the types of prayers have evolved. Thomas Machell, an indigo merchant who worked in India, observed the practice of a ritual called $z i k r$ (dhikr) while traveling by sea from Persia (now Iran) to Jeddah in 1848. As part of this ritual, Arabian mariners burned frankincense and made bodily convulsions while repeatedly chanting ya Allāh. ${ }^{67}$ However, this practice seems to have been abandoned, because none of my informants recalled it.

\section{The Tomb Visitation (ziyāra)}

The visiting of saints' tombs (ziyārāt al-qubūr) goes back to early Islam. ${ }^{68}$ Praying at the tombs of Muslim saints is also a continuation of the practices designed to propitiate nature, a practice that derives from "ancestral worship. ${ }^{69}$ A sacrifice of a sheep is made to the saint in gratitude for the prayers heard, a favor, or protection. The sacrificial sheep is then shared with people, the poor and the needy. Sacrifices were made in pre-Islamic days under a sacred tree to propitiate gods and spirits: "For most of human history," posited Carolyn Merchant, "nonhuman nature has power over humans. People accepted fate while propitiating nature with gifts, sacrifices, and prayer... ${ }^{70}$ The saint's tomb has replaced the tree.

Travelers visit saints' tombs to plead for salvation in difficult circumstances and to receive blessings (baraka). This is a common folk practice in many places of the western Indian Ocean (including the Red Sea). Saints' tombs are often cuboid in shape with a dome on top and constitute "a significant portion of Islamic art." ${ }^{\text {"11 }}$ In general, they are whitewashed with lime made of burnt sea shells. Such tombs exist all along the coastlines of Arabia, northeast Africa, and west India. They are typical of the ziyāra (visitation) cult. Each of these tombs has its own associated rituals. Sharing 
of food or money with people is an important element in the rituals. At the Shaykh al-Shādhilì's tomb in Mocha on the Yemeni coast, there is an annual gathering of devotees sharing food. One interesting ritual recorded by Joseph Pitts (d. 1735 [?]), a captured slave by the Algerian pirates and taken by his master to Mecca, describes a Red Sea practice in c. 1685 on board ship to Jeddah. He observed the crew placing a wax candle contained in a bottle of oil that they placed on a model boat with some money and then sailing it toward the holy man's burial, raising their hands, asking for blessing, and praying for a good voyage. ${ }^{72}$ The money is a gesture of sharing with the poor people on the coast via the holy man's tomb. At a number of tombs in the Tihama, it is customary for visitors to leave behind sawfish snouts as a sign of gratitude for, as Francine Stone noted, "introducing the skill of net fishing, thereby unlocking the riches of the sea."73 Ali Chehem Mohamad from Tadjoura, in his forties, informed me that local villagers and fishermen leave food offerings at the tomb of Shaykh Muhammad near Tadjoura to be shared with the poor ${ }^{74}$ (Figure 9). According to Crossland, at the turn of the twentieth century ritual offerings of food and/or water were occasionally offered to the sea by men on board ships passing by coastal tombs, as has been recorded at Shaykh Ishāà's tomb on Maydh Island (Figure 10$)^{75}$ and Shaykh Barūd's burial place on the Arabian coast. ${ }^{76}$ This practice was unknown to my informants.

In his account of the Sudanese coastal landscape, Crossland called this tomb visitation "a fine example indeed of a persistent widespread, and very ancient observance." 78 The tomb is believed to have "miraculous power," and that is why it is frequented by the sailor and traveler. That this practice and its concept come from "ancestral worship"79 warrants further study. Such tombs are set up on high ground, and perform the dual purpose of also being landmarks for passing ships.

\section{The Jinn Cult}

Midshipman John E. Conant on his 1795 voyage into the Red Sea wrote that people saw this sea as "the abode of spirits[,] that phantoms hovered in the waters and that ghosts stalked upon the strands." ${ }^{80}$ It is an interesting description of the working of spirits. The belief in spirits at work in the Red Sea exists today as it did in the past: Many believe that the winds and 


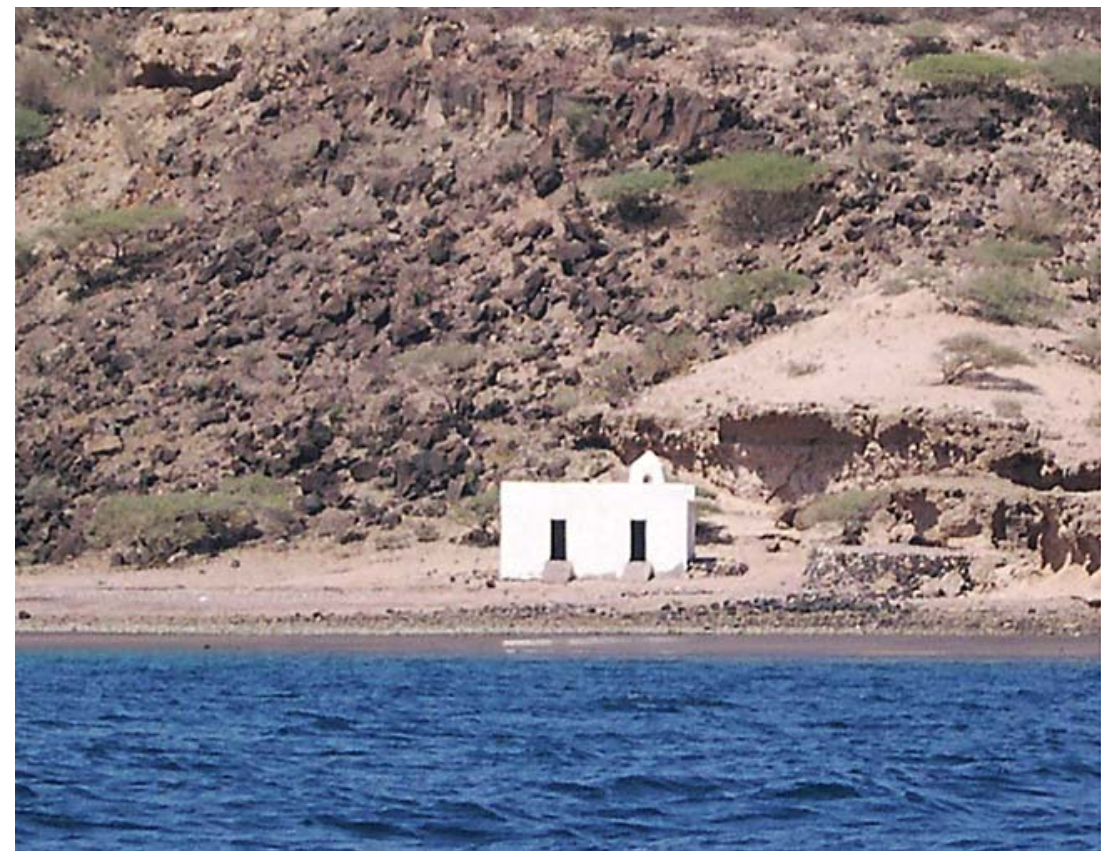

Figure 9. Shaykh Muḥammad's tomb near Tadjoura, Djibouti, 2009. (Photo by D. A. Agius.)

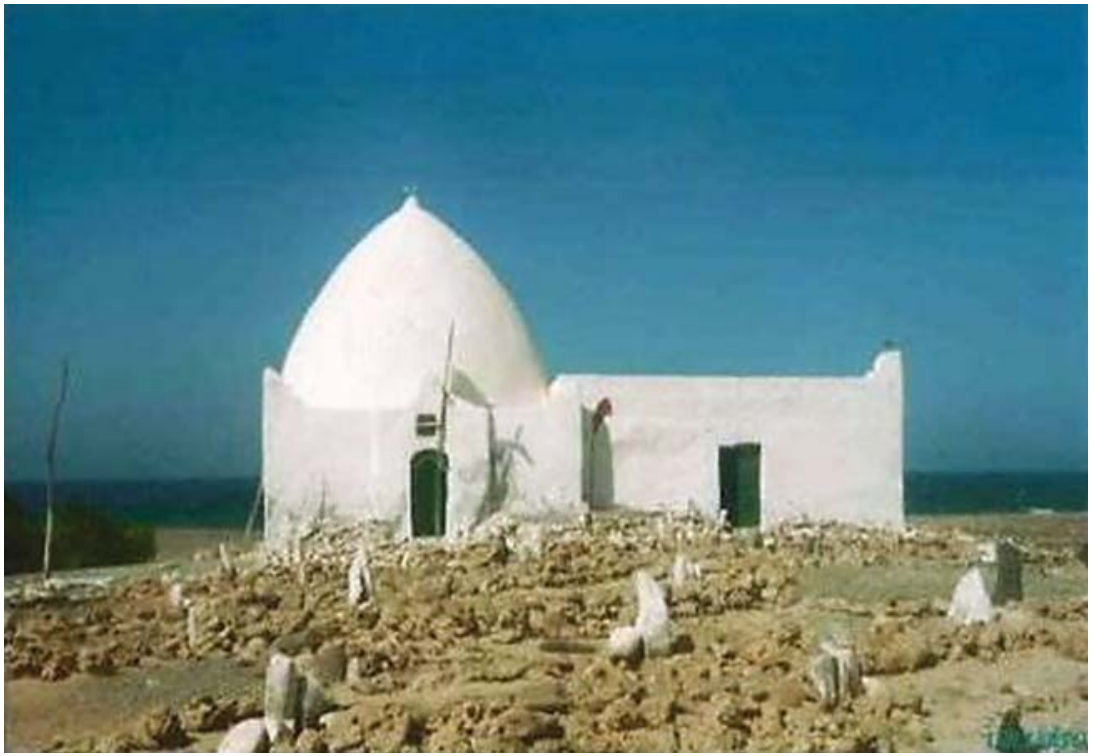

Figure 10. Shaykh Isḥāq's tomb at Maydh Island, Sanaag, Somalia (Photo by A. Basid Ismail. $)^{77}$ 
currents of this merciless sea are the works of evil spirits. It is the belief of the Hadandiwa tribe in Sudan that the Red Sea is "infested with immortal, deceptive spirits." ${ }^{81}$ These are the jinns. Well-known in pre-Islamic Arabia, they are "the nymphs and satyrs of the desert." ${ }^{82}$ Sanctioned by the Qur'ānic "Sūrat al-Jinn" (Chapter on jinns) ${ }^{83}$ and verses from a few other chapters, ${ }^{84}$ the belief in jinns is popular and widespread in the Islamic world. The Qur'ān describes jinns as spirits created "from fire free of smoke" 85 and "from the fire of a scorching wind." ${ }^{66}$ By contrast, the Qur'ān states that humans were created "from mud moulded into shape." ${ }^{\text {87 }}$ Iinns are believed to have the ability to take a variety of forms, including those of animals, typically cats and dogs, or of humans of any age, gender, religion, or status. ${ }^{88}$

When I raised the topic of jinns with several of my informants on both the African and Arabian shores, not all were ready to talk about them. For example, when I brought up the subject at an evening gathering hosted by Saeed Al-Yarmi on Farasan Island, some of the assembled men looked uncomfortable. These were educated, high-ranking civil servants. They remarked that they found jinns entertaining like the Arabian Nights but declined to say whether they believed in them. This reticence was unusual, as I had previously found a wide-spread belief in jinns, openly expressed by the fishing communities, who readily attributed setbacks to the work of the jinns. Both educated and noneducated classes burn incense in their homes to keep the jinns out, a practice that was explained to me several times by mariners. A more typical reaction came from Abdo Mohammed Aqili, also at the gathering, a fisherman and a part-time pearl diver, 46 years old, who gave us this account of jinns that meet in a cave at Shida on Greater Farasan close to the sea:

If you enter it by descending some uneven steps you come to a large chamber with beautiful sparkling objects around. You may enter a second chamber and you find a one-eyed creature. If you succeed to bypass this creature you will come to another cave and from there to other caves but leading to nowhere as the whole place is a labyrinth which only jinns know.

At the end Abdo told us that "if we were to offer loyalty to the master jinn, we would be spared of any evil" 89 (Figure 11). The probable explanation for the reaction of the civil servants to the belief in jinns in Farasan is because 


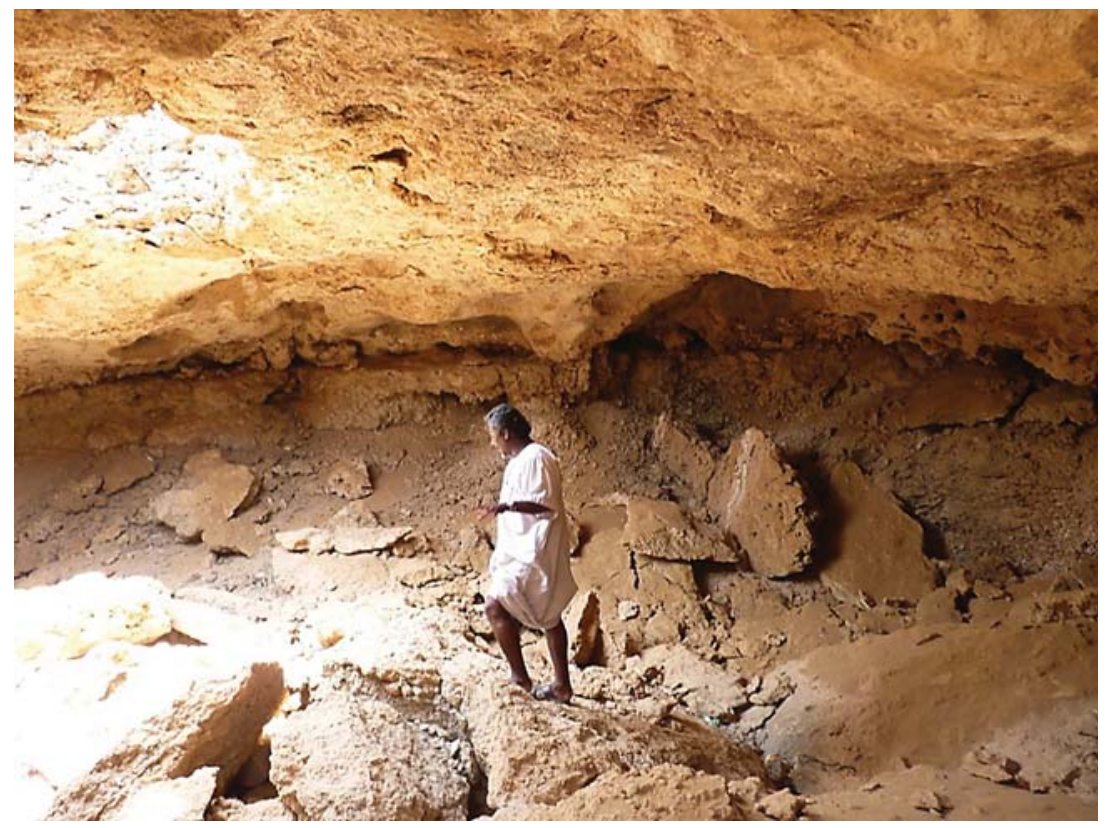

Figure 11. Abdo Aqili at the entrance of Shida, on Greater Farasan Island: the cave where the jinns assemble, 2010. (Photo by D. A. Agius.)

their lives are now distant from the maritime world unlike the fishermen who are still part of that world where it is taken for granted that the jinns interact with human beings.

In my fieldwork, I found a general belief that jinns live alongside the people of the Farasan Archipelago. This belief is an echo of what Oliver Myers reports in his 1947 survey at Ras Imran, West Little Aden, where people told him that jinns dwell in the volcanic peninsula. He reported: "If a man ... hears the jinns calling him," he risks "to be carried off or else drops down dead at the sight of them." ${ }^{90}$ In the 1960s, Donald Foster also states that Little Aden was a place "crowded" with male and female jinns. ${ }^{91}$ A Farasani claimed that "a pregnant genie could carry nine infant jinns." ${ }^{\text {" I }}$ asked Abdo Aqili about their presence on the islands. In a hushed tone he told me: "They are everywhere." I asked whether he ever saw one; "Aaah, they are invisible creatures: they see you but you don't," was his reply. ${ }^{93}$

Jinns are said to inhabit abandoned settlements such as the old village of Qusar on Greater Farasan Island. Farasanis believe that what was once a thriving summer resort has now become a haunted place believed to 
be inhabited by land and sea jinns. Some thirty houses were deserted; no satisfactory reason other than this jinn occupation was offered. Similar stories were heard in Abu Dhabi from a dhow builder from Hamra Island, Sultan Muhammad Al Zaabi, 65 years old; he said: "many islanders, young and old, fear the magic (sihr) of the jinn on the island and at sea-the Abu Khațāf [a swift catcher]." ${ }^{94}$ That jinns haunt houses and whole villages is a not uncommon Red Sea belief. Elsewhere, the folklorist E. W. Lane (d. 1876) reports that Egyptians claimed that jinns inhabited "ruined houses and wells. ${ }^{\prime 95}$ They seem to like the dark night and take human beings by surprise and "very often station themselves on the roofs, or at the windows, of houses ... and throw bricks and stones down into the streets and courts." ${ }^{96}$ In his exhaustive account on jinn lore and legends, Robert Lebling says that people in Saudi Arabia would "avoid houses and other buildings" that are suspected of being occupied by jinns. ${ }^{97}$ In Aden, Myers's informants told him that jinns beat the drums when people are not around. ${ }^{98}$ His informants claimed that they come and go in seconds, and travel long distances in no time. They are a "hidden force" that can both manifest on their own and that can be summoned..$^{99}$

Mariners fear the presence of jinns at certain anchorages. The French master mariner, Henri de Monfreid (d. 1974) reported that the crew of one ship was afraid to go ashore north of Assab, Eritrea. ${ }^{100}$ Similar information was conveyed to me by Youssef Omar Mohamed, a sea captain of Obock, Djibouti, 77 years old. This captain claimed that sailors feared to go ashore on Sukuti, an arid island off the Yemeni coast. He recalled: "They would call on the name of a shaykh and recite a verse from the Qur'ān and would not utter a word thereafter"; thus, he explained, the island was called Sukuti, signifying "a silent [place]."101 This fear of jinns often translates into a fear of mountain spirits. At Quseir on Egypt's Red Sea coast, I was told that people are often reluctant to travel alone in mountainous regions near the coast because of the malevolent and powerful demons - afreets ( ${ }^{c}$ afrit $) .{ }^{102}$

Shipwrecks are thought to be caused by sea jinns. The Swiss traveler, Johann Ludwig Burckhardt (d. 1817), sailing from Yanbu al-Bahr (Saudi coast) to Quseir (Egyptian coast) on a sanbūk, observed how Arabian mariners "hold certain passages [in the Red Sea] in great horror; not because they are more dangerous than others but because they believe that evil spirits dwell among the coral rocks, and might possibly attract the ship towards the shoal, and cause her to founder."103 Legends have it that 
sea jinns sing to attract mariners to the reefs causing their boats to wreck, though de Monfreid, who knew well the southern Red Sea, interpreted this to be the crickets' "immense clamour" which was so loud that it lulled the helmsman to "a hypnotic sleep,"104 thus losing control of the boat. Sadek Yakoub Abdalla, a 55-year old sea captain from Obock, Djibouti, asserted that jinns can manifest themselves as light misguiding a ship to destruction. He recalled:

Once, we were heading for Djibouti city from Tadjoura and we saw a dhow which we suspected was operated by jinns. The dhow had lights consisting of three colors: the bow's sides were white and that of the stern's right side was green, while the left side was red. Now, normally you sailed to the right side of the dhow, that is, the green light, in order to sail safely to the coast; however, because this ship was possessed by jinns, we avoided the green light as we correctly suspected that it would trick us and the dhow would have been grounded on rocks and broken to pieces.

He called this type of jinn that plays with peoples' minds in order to dissuade the crew from sailing correctly the mughawwi $\bar{\iota}^{105}$

People routinely use the mischievous nature of jinns to explain unexplainable everyday phenomena. For example, Muhammad Abd Allah Abbas, a fisherman in his 70s from Qumah Island at Farasan, said to me: "Once I left something on the shore; I came back to find nothing there. The jinn had taken it." I asked, "Might it not be that someone passing by picked it up?" He replied, "There was nobody around at that time." He then related another story: "Some fishermen were fishing in a dug-out hürī not far from where I was standing on the shore. All of a sudden they were carried away by some jinn, never to come back."106

Coastal people and mariners have found ways to protect themselves against jinns. Ethnolinguist Bob Serjeant, cited by Rex Smith, says that ashes "against the [jinns]" are considered a suitable offering to keep them at bay. ${ }^{107}$ Coconut is offered by sailors arriving from East Africa at Ras Hafun on the Somali coast; they place the coconut in model boats "for the [jinns] to pacify them."108 At Gardafui (known as Ras Asir) in today's Puntland, sailors put food in a box and let it flow on the sea. This they believed would appease the anger of the mountain jinns and by doing so they would liberate themselves from their hold on them. ${ }^{109}$ There is also a belief, noted 
by Myers in the 1940s, though not confirmed by my informants at Seerah and Kheesa in Aden, that "gifts" to the sea jinns attract good catches of fish. An interesting point is that this is "parallel to gifts to inland deities to bring better crops and yields from the herds." ${ }^{\prime 10}$ These practices echo those of earlier periods. Burckhardt remarked on his journey from Yanbu al-Bahr to Quseir about “[the crew's] constant practice of throwing, at every meal, a handful of dressed victuals into the sea, before they sit down themselves to the repast; saying that the inhabitants of the sea must also have their morsel, otherwise they will impede the vessel's course." this specific custom was not mentioned in my meetings with present-day informants, Myers's 1947 survey demonstrated that it continued into the twentieth century. ${ }^{112}$ The fear of thunder, lightning, and gales as they blow unpredictably in the Red Sea brings people together to offer gifts; thus propitiation is essential to pacify or appease or expiate.

On land, people customarily place Qur'ānic verses in the corner of the foundations of a house to counteract the presence of jinns. My coethnographer Muhammad Alhazmi, a Saudi, and I uncovered sections of the Qur'ān in the rubble wall of a ruined house on the coast at Yanbu al-Bahr in April 2013. The custom has spread, we are told, to newly built homes (Figures 12 and 13). No particular verses were chosen for such practice as long as it seems they are verses from any part of the Qur'ân.

\section{Conclusion}

It would seem that the turbulent nature of the Red Sea is reflected in the need for beliefs that give positive protective measures against destructive elemental powers. The physical, cognitive, language, and linguistic —along with the interplay of human and nonhuman elements - all figure prominently in sea folk beliefs. These beliefs are deeply rooted in the natural world. They provide an insight as to how people think and what meaning they give to their lives. Examples drawn from the oral and written accounts demonstrate continuity with some folk beliefs and practice but discontinuity with others. Where there is continuity this does not imply stasis; as my own fieldwork has detected, there are some differences of practice, for example the throwing of food into the sea as a form of appeasement to the spirits has fallen into disuse but leaving food at the saints' tombs has 


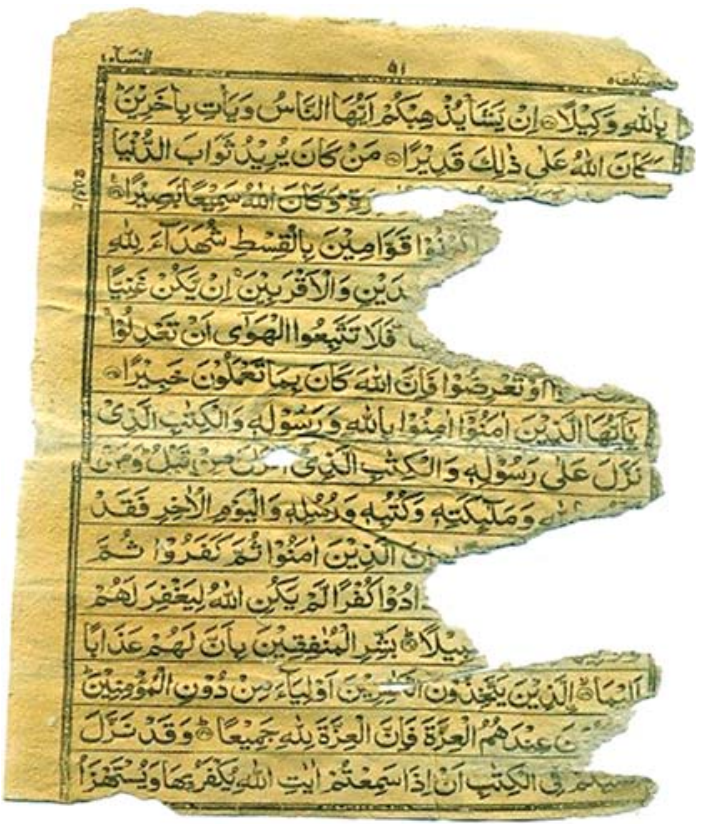

Figures 12 and 13. A Qur'ānic section found at a corner of a ruined merchant house at Yanbu al-Bahr, Saudi Arabia, 2013. (Photo by D. A. Agius.)

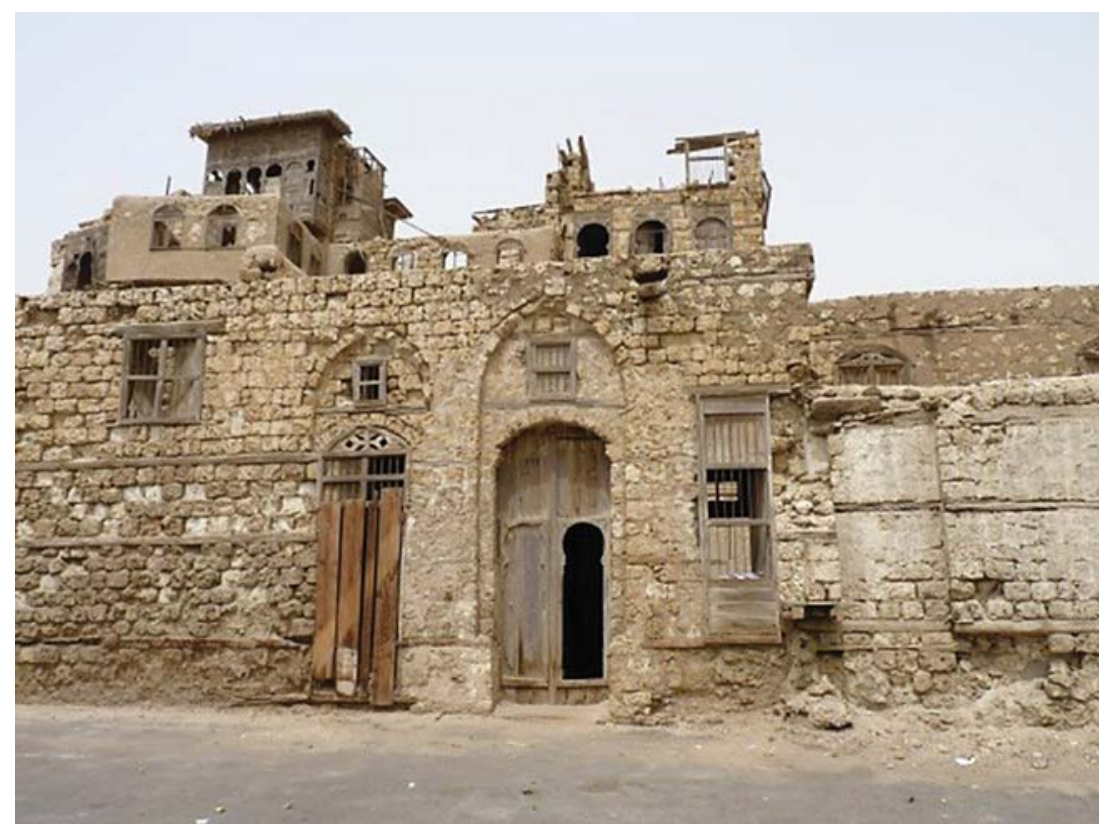


persisted. Both practices almost certainly predate Islam, but the offering of food at the tomb chimes with Islam in that it combines the spiritual with the obligation to share with the poor.

No claim for a unique Red Sea pattern of folk belief and superstition can be made. There are similarities in many respects to global sea folk beliefs and in particular to those of neighboring regions. Recognizing the power of nature and giving it the ability to intervene are pre-Islamic beliefs that continue to this day and are all part of what appears to be a homogenous maritime culture of the Red Sea, but also one that is shared with the rest of the western Indian Ocean coastal communities. The movement of peoples from North and sub-Saharan Africa and from India must surely have affected the spiritscape of the Red Sea but this would warrant a much wider study.

Offerings made to mountains, the wearing of amulets, decorating the dhows with ostrich feathers, tassels, and oculus are all manifestations of protective measures, but a custom with "pragmatic or emotional value" can fall into disuse. ${ }^{113}$ What could be the reasons for this? One pragmatic reason why some protective measures have been discontinued is that the perilous days of sailing disappeared with the introduction of motorized vessels that could reach destinations in a much shorter time. The fear and anxiety has been minimized because people's trust is to some extent transferred to a reliance on technology, even though maritime accidents do still occur.

The Islamic religious prohibition on reproducing nature may also be a factor. Thus, the representation of "the eye" is officially prohibited by most Islamic authorities; food offerings to the sea and mountains have shamanistic roots that the religious shari' $a$ law would not allow; and the wearing of amulets, unless they contain Qur'ānic verses, is not looked upon favorably. There has undoubtedly been a resurgence of Islam in the past forty years and this could well be why some of the practices were discontinued, as a response to a stricter application of the principles of Islam.

And yet historical practices still structure the folk beliefs of the Red Sea seascape. Some dhow owners still paint their dhows in vivid colors and display multidimensional geometrical figures as a talismanic device against evil forces whereas in southern Arabia and the Gulf today dhows display no colors or little decorative motifs. The physical and the cognitive human and nonhuman factors are still alive: The visiting of saints' tombs, dotted along the African and Arabian shores has that "emotional significance"114 
seafarers and the local communities experience because of the protection or favor they receive. The overwhelming belief in spirits (jinns), predating Islam, is powerful as oral accounts confirm and it is my impression from the fieldwork undertaken that the belief in jinns is far greater in and around the Red Sea than other neighboring regions. The persistent belief in superstition and folklore practices in the Red Sea could be partly due to the relative poverty of many of its populations and, therefore, the continuing prevalence of fishing and small trading as an occupation on its coasts. Because of this continuing interaction with the seascape, facing the dangers of its waters, the need is still felt for protective measures against the spirits who personify the natural hazards of this world.

\section{NOTES}

I would like to thank King Abdulaziz University, Jeddah; the MARESGoldenWeb Foundation; the Saudi Commission for Tourism and Antiquities and Seven Pillars of Wisdom Trust which made the study possible. I am grateful to Stephen Serels and the anonymous reviewers for their helpful suggestions which were included in this revised version.

1. Sūrat Luqmān 31: 32; translation by Yusuf Ali: The Holy Quran: Text, Translation and Commentary, vol. 2 (Cambridge, MA: Hafner, 1946), 1088.

2. Nikki Bado-Fralick, "Folk belief," in Encyclopedia of the Great Plains, ed. D. J. Wishart, accessed November 19, 2015, http://plainshumanities.unl.edu/ encyclopedia/doc/egp.fol.013.

3. Richard M. Dorson, "Current Folklore Theories," Current Anthropology 4, no. 1 (1963): 110.

4. James Hornell, "Survivals of the Use of Oculi in Modern Boats," Journal of the Royal Anthropological Institute of Great Britain and Ireland 53, no. 2 (1923): 289-321; James Hornell, "Boat Oculi Survivals: Additional Records," Journal of the Royal Anthropological Institute of Great Britain and Ireland 68, no. 2 (1938): 339-49.

5. Oliver H. Myers, "Little Aden Folklore," Bulletin de l'Institut Français d'Archéologie Orientale 44 (1947): 177-233.

6. Richard LeBaron Bowen, "Maritime Superstitions of the Arabs," American Neptune 15, no. 1 (1955): 5-48; Richard LeBaron Bowen, "Origin and Diffusion of Oculi," American Neptune 17, no. 4 (1957): 262-91. 
7. Robert B. Serjeant, "Maritime Customary Law Off the Arabian Coasts," in Sociétés et Compagnies de Commerce en Orient et dans l'Océan Indien, ed. Michel Mollat (Paris: SEVPEN, 1970), 195-207.

8. T. M. Johnstone, "Folklore and Folk Literature," Arabian Studies 1 (1974): $7-25$.

9. V. V. Naumkin, Island of the Phoenix. An Ethnographic Study of the People of Socotra (Reading: Ithaca, 1993); V. V. Naumkin, "Myth, Gender and Eroticism in Socotran Folklore," Proceedings of the Seminar for Arabian Studies 31 (2001): 189-94.

10. Rex Smith, "Magic, Jinn and the Supernatural in Medieval Yemen: Examples from Ibn al-Muğāwir's $7^{\text {th }} / 13^{\text {th }}$ Century Guide," Quaderni di Studi Arabi 13 (1995): 7-18.

11. See Tommy Kuusela and Giuseppe Maiello, eds., Folk Belief and Traditions of the Supernatural (Inverness: Beewolf, 2016).

12. Hildred Geertz, "An Anthropology of Religion and Magic, 1," Journal of Interdisciplinary History 6, no. 1 (1975): 78; Talal Asad, "Anthropological Conceptions of Religion: Reflections on Geertz," Man, New Series, 18, no. 2 (1983): 237, 239.

13. C. Westerdahl, "The Maritime Cultural Landscape," International Journal of Nautical Archaeology 21, no. 1 (1992): 5-14; C. Westerdahl, "Fish and Ships: Towards a Theory of Maritime Culture," Sozialgeschichte der Schifffahrt 30 (2008): 191-230.

14. D. B. Tuddenham, "Maritime Cultural Landscapes, Maritimity and Quasi Objects," Journal of Maritime Archaeology 5, no. 1 (2010): 8-11; see also J. Vaz Freire "Maritime Cultural Landscape: A New Approach to the Cascais Coastline," Journal of Maritime Archaeology 9, no. 1 (2014): 145.

15. Tuddenham, "Maritime Cultural Landscapes, Maritimity and Quasi Objects," 8.

16. Ibid., 10

17. Vaz Freire, "Maritime Cultural Landscape," 145-6.

18. D. Matsumoto, Culture and Psychology (Pacific Grove, CA: Brooks/Cole, 1996), 16.

19. Stuart A. Vyse, Believing in Magic: The Psychology of Superstition (Oxford: Oxford University Press, 1977), 21.

20. This fieldwork was part of a wider study undertaken by the MARES (Maritime Ethnography of the Arabian Gulf and the Red Sea: People, Trade and Pilgrimage) research project at Exeter University (2009-11). The 
project focused on the maritime tangible and intangible culture of the southern Red Sea region with the aim of understanding how people have inhabited and navigated these seascapes.

21. "Djibouti," accessed May 19, 2017, https://www.britannica.com/place/ Djibouti.

22. A. Rouaud, "Tadjurra," Encyclopaedia of Islam, 2nd ed., vol. 10 (Leiden, The Netherlands: Brill, 2000), 71.

23. See ${ }^{\mathrm{c} A w a d ̣ ~ D a ̄ u ̄ d ~ M u h a m m a d, ~ A l-M a s ' a l a ~ l-c ~ A f a r i y y a ~ f i ́ ~ l-q a r n ~ a l-I f r i ̄ q u ̄ ~}$ (Cairo: Jāmicat al-Duwal al-cArabiyya, 1993), 26-40; 41-55.

24. Map drawn by author.

25. W. Gladstone, "Fisheries of the Farasan Islands (Red Sea)," accessed November 11, 2015, http://core.ac.uk/download/pdf/11023726.pdf.

26. Mohammad Abdalla Mohammad Abbas, in his 70s, interviewed on May 23, 2010.

27. See Roxani Eleni Margariti, Aden and the Indian Ocean Trade (Chapel Hill, NC: University of North Carolina Press, 2007); Jonathan Miran, Red Sea Citizens: Cosmopolitan Society and Cultural Change in Massawa (Bloomington, IN: Indiana University Press, 2009); Alexis Wick, The Red Sea: In Search of Lost Space (Berkeley and Los Angeles: University of California Press, 2016).

28. See my forthcoming book, Dionisius A. Agius, The Life of the Red Sea Dhow: A Cultural History of Seaborne Exploration in the Islamic World (London: IB Tauris, 2018).

29. Ibn al-Mujāwir, $A$ Traveller in Thirteenth-Century Arabia: Ibn al-Mujāwir's Tärïkh al-mustabșir, trans. and annotated by G. Rex Smith (London: The Hakluyt Society, 2007), 136, also fn. 3.

30. Al-Nuwayrī l-Iskandarānī, Kitāa al-ilmām bil-iclām fì mā jarat bihi l-ahkkām wa-l-umūr al-muqdiya fì waq at al-Iskandariyya, vol. 2 (Hyderabad: Dāirat al-Macārif al- 'Uthmāniyya, 1968-76), 248.

31. James Raymond Wellsted, Travels in Arabia, vol. 2 (Graz: Akademische Druck-u. Verlagsanstalt, 1978), 465.

32. Myers, "Little Aden Folklore," 220.

33. Thomas Bertram, Arabia Felix: Across the Empty Quarter of Arabia (London: Jonathan Cape, 1932), 41.

34. Ibid., 157.

35. T. Fahd, "Sihr," Encyclopaedia of Islam, 2nd ed., vol. 9 (Leiden, The Netherlands: Brill, 1997), 567. 
36. Sonja Hukantaival, "Finding Folk Religion: An Archaeology of Strange Behaviour," Journal of Folklore 55 (2013): 105.

37. See, for example, Ronald A. Reminick, "The Evil Eye Belief among the Amhara," in The Evil Eye, ed. Clarence Maloney (New York, NY: Columbia University Press, 1976), 85-101; Aref Abu-Rabia, "The Evil Eye and Cultural Beliefs among the Bedouin Tribes of the Negev, Middle East [1]," Folklore 116 (2005): 241-54.

38. R. B. Serjeant, The Portuguese off the South Arabian Coast (Beirut, Lebanon: Librairie du Liban, 1974), 137.

39. Beatrice Nicolini, "Some Thoughts of the Magical Practice of the $z \bar{a} r$ along the Red Sea in the Sudan," in People of the Red Sea: Proceedings of Red Sea Project II, ed. J. C. M. Starkey, Society for Arabian Studies Monographs, no. 3 (Oxford: Archaeopress, 2005), 160.

40. See Hildred Geertz, "An Anthropology of Religion and Magic, 1," Journal of Interdisciplinary History 6, no. 1 (1975): 79.

41. Dionisius A. Agius, "Decorative Motifs on Red Sea Boats: Meaning and Identity," in Natural Resources and Cultural Connections of the Red Sea. Proceedings of Red Sea Project III, eds. Janet Starkey, Paul Starkey, and Tony Wilkinson, Society for Arabian Studies Monographs No. 5 (Oxford: Archaeopress, 2007), 104-5.

42. Hornell, "Survivals of the Use of Oculi," 289-321; Hornell, "Boat Oculi Survivals," 339-49; James Hornell, Water Transport: Origins and Early Evolution (Cambridge: Cambridge University Press, 1946), 285.

43. Bowen, "Maritime Superstitions of the Arabs," 6, 12.

44. Clifford W. Hawkins, The Dhow: An Illustrated History of the Dhow and Its World (Lymington, Hampshire: Nautical Publishing, 1977), 78.

45. Alan Moore, "Notes on Dhows," The Mariner's Mirror 26, no. 2 (1940): 205.

46. Bowen, "Maritime Superstitions of the Arabs," Fig. 1.

47. Agius, "Decorative Motifs on Red Sea boats," 106-7.

48. Ibid., 109.

49. R. Morton Nance, "Terradas and Talismans," The Mariner's Mirror 4, no. 1 (1914): 8, 10.

50. See William Foster, ed., The Red Sea and Adjacent Countries at the Close of the Seventeenth Century (Liechtenstein: Kraus Reprint, 1967), 19, 73.

51. Dionisius A. Agius, “Leave Your Homeland in Search of Prosperity': The Ostrich Egg in a Burial Site at Quseir al-Qadim in the Mamluk Period," in Egypt and Syria in the Fatimid, Ayyubid and Mamluk Eras, eds. U. 
Vermeulen and J. Van Steenbergen (Leuven: Peeters, 2005), 370-72, 378-79.

52. Nance, “Terradas and Talismans," 9.

53. N. F. J. Wilson, The Native Craft: A General Description of the Native Craft Visiting Bombay Harbour and Particulars as to Their Survey, Registry, Measurement and Lighting (Bombay: Times Press, 1909), 103.

54. Interview on February 28, 2011.

55. Interview on November 24, 2004.

56. Wilfred H. Schoff, "Cinnamon, Cassia and Somaliland," Journal of the American Oriental Society 40 (1920): 260.

57. Cyril Crossland, Desert and Water Gardens of the Red Sea (Cambridge: Cambridge University Press, 2010), 39.

58. J. G. Frazer, The New Golden Bough: A Study in Magic and Religion (First published 1890; reprt. New York: Macmillan, 1959); B. Malinowski, Magic, Science, and Religion (Garden City, NY: Doubleday, 1954).

59. Gloria Keinan, "The Effects of Stress and Desire for Control on Superstitious Behavior," Personality and Social Psychology Bulletin 28, no. 1 (2002): 102-8.

60. L. Gardet, "Dư'ā'," Encyclopaedia of Islam, 2nd ed., vol. 2 (Leiden, The Netherlands: Brill, 1965), 617; Sūrat Hāmīm, 41: 49, 51.

61. Sūrat Yūnus, 10: 22.

62. Information from Sadek Yakoub Abdalla, October 22, 2009.

63. Munā Bint Muḥammad Aḥmad Hubaylī and Laylā Bint Muḥammad Aḥmad Hubaylī, rev. and ed. Fāṭima Al-Ḥarbī, Jazīrat Farasān: Al-tārīkh wa l-siyāḥa (Jizan: Mațābic Jāzān, 1431/2009), 33.

64. Ibn Bațūța, Voyages d'Ibn Battûta, Arabic text with translation by C. Defrémery and B. R. Sanguinetti, vol. 1 (Paris: Anthropos, 1968), 42,

65. Richard F. Burton, Personal Narrative of a Pilgrimage to Al-Madinah and Meccah, vol. 1 (first published 1893; reprt. New York: Dover, 1964), 211-2.

66. Lawrence L. Conrad, "Islam and the Sea: Paradigms and Problematics," Al-Qantara 23, no. 1 (2002): 152.

67. British Library - India Office Records: BL, IOR/MSS EUR B369/1 (T. Machell, 1840-1848), ff. 187-8.

68. . Linant de Bellefonds, “Kabr," Encyclopaedia of Islam, 2nd ed., vol. 4 (Leiden, The Netherlands: Brill, 1990), 354-5.

69. Crossland, Desert and Water Gardens of the Red Sea, 38.

70. Carolyn Merchant, "Reinventing Eden: Western Culture as a Recovery 
Narrative," in Uncommon Ground: Rethinking the Human Place in Nature, ed. William Cronon (London: Norton, 1996), 158.

71. J. Sourdel-Thomine, "Kabr," Encyclopaedia of Islam, 2nd ed., vol. 4 (Leiden, The Netherlands: Brill, 1990), 352.

72. Paul Auchterlonie, Encountering Islam. Joseph Pitts: An English Slave in 17th-Century Algiers and Mecca (London: Arabian Publishing, 2012), 184.

73. Francine Stone, "Notes on the Crafts, Customs and Local Industries of the North Yemen Tihāmah," in Studies on the Tihāmah: The Report of the Tihāmah Expedition 1982, ed. Francine Stone (Harlow, Essex: Longman, 1985), 121, see also fn. 79.

74. Interviewed on October 20, 2009.

75. Henri de Monfreid, Secrets of the Red Sea, trans. Helen Buchanan Bell (London: Faber and Faber, 1934), 290; see also Ida Treat, Pearls Arms and Hashish (London: Victor Gollancz, 1930), 252-3.

76. Crossland, Desert and Water Gardens of the Red Sea, 37.

77. Wikipedia, accessed May 6, 2015, https://commons.wikimedia.org/wiki/ File:Sheikhisaaqmaydh.jpg.

78. Crossland, Desert and Water Gardens of the Red Sea, 37.

79. Ibid., 38.

80. Lyndon Estate (Private) Manuscript (Oakham, Rutland) "Journal of a voyage into the Red Sea," (1795), fol 5.

81. Nicolini, "Some thoughts of the Magical Practice," 159.

82. D. B. Macdonald [H. Massé], "Djinn," Encyclopaedia of Islam, 2nd ed., vol. 2 (Leiden, The Netherlands: Brill, 1965), 547.

83. Sūrat al-Jinn 72: 1-28.

84. Sūrat al-Hijr 15: 27; Sūrat Sabā 34: 41; Sūrat al-Aḥqāf 46: 29-32; Sūrat alRaḥmān 55: 15

85. Sūrat al-Raḥmān 55: 15; translation by Yusuf Ali, The Holy Quran II: 1474.

86. Sūrat al-Hijr (15: 27); translation by Yusuf Ali, The Holy Quran 1: 642.

87. Sūrat al-Hijr (15: 26); translation by Yusuf Ali, The Holy Quran 1: 642; see also Edward W. Lane, An Account of the Manners and Customs of the Modern Egyptians, vol. 1 (London: Charles Knight, 1842), 339; Robert Lebling, Legends of the Fire Spirits: Jinn and Genies from Arabia to Zanzibar (London: I.B. Tauris, 2014), 77-80.

88. Macdonald [H. Massé], "Djinn," 548; see Lebling, Legends of the Fire Spirits, 94.

89. Information gathered on May 24, 2010. 
90. Myers, "Little Aden Folklore," 215.

91. Donald Foster, Landscape with Arabs: Travels in Aden and South Arabia (London: Clifton, 1969), 177.

92. Interview on May 20, 2010.

93. Interview on May 11, 2010.

94. Interview on June 7, 2015.

95. Lane, An Account of the Manners and Customs of the Modern Egyptians, 1: 337.

96. Ibid., 341.

97. Lebling, Legends of the Fire Spirits, 77.

98. Myers, "Little Aden Folklore," 198.

99. Ali, The Holy Quran, 1: 319, fn. 929.

100. De Monfreid, Secrets of the Red Sea, 48.

101. Interviewed on October 22, 2009.

102. Interview with Kamil Muhammad al-Burri, February 9, 2004, and Abbas Muhammed Ali Daud, on February 10, 2004.

103. Johann Ludwig Burckhardt, Travels in Arabia (London: Henry Colburn, 1829), 429.

104. De Montfreid, Secrets of the Red Sea, 48.

105. Interviewed on October 22, 2009.

106. Interviewed on May 23, 2010.

107. See Ibn al-Mujāwir, A Traveller in Thirteenth-Century Arabia, 136, also fn. 5.

108. Serjeant, "Maritime Customary Law Off the Arabian Coasts," 199.

109. Ibid.

110. Myers, "Little Aden Folklore," 220.

111. Burckhardt, Travels in Arabia, 429.

112. Myers, "Little Aden Folklore," 220.

113. See Geertz, "An Anthropology of Religion and Magic, 1," 79.

114. See Asad, “Anthropological Conceptions of Religion,” 240.

\section{ABOUT THE AUTHOR}

Dionisius A. Agius is Emeritus Al-Qasimi Professor of Arabic Studies \& Islamic Material Culture at the University of Exeter. 
